\title{
Lymphocytes Binding C-Reactive Protein during Acute Rheumatic Fever
}

\author{
Ralph C. Williams, Jr., and K. A. Kilpatrick, Department of Medicine, \\ University of New Mexico School of Medicine, Bernalillo County Medical Center, \\ Albuquerque, New Mexico 87131 \\ M. KASSABY and Z. H. ABDIN, Department of Pediatrics, Free Rheumatic Heart Center, \\ Cairo, Egypt
}

\begin{abstract}
A B S T RA C T Lymphocytes binding C-reactive protein (CRP) were studied in 31 patients with acute rheumatic fever and 30 controls who were children. Marked elevations in both proportions and absolute numbers of CRP-binding lymphocytes were recorded in rheumatic fever $(P<0.001)$. No clear correlation was noted between plasma CRP as quantitated by radioimmunoassay and proportions or numbers of CRP-binding cells. Double-labeling experiments indicated that $60-80 \%$ of CRP-binding lymphocytes also showed $\mathrm{Fc}$ receptors reacting with fluorescein-conjugated IgG aggregates. Passage of lymphocytes over Ig-anti-IgG columns, removed cells bearing surface Ig but not CRP-binding lymphocytes. Studies of T-cell subpopulations indicated no overlap between $\mathrm{T} \mu$ - and CRP-binding cells; however about half of $\mathrm{T} \gamma$-cells showed concurrent CRP binding. "Active" T-cell rosetting cells did not bind CRP. A 12-15-h incubation of lymphocytes at $37^{\circ} \mathrm{C}$ in $5 \% \mathrm{CO}_{2}$-air showed persistence of CRP binding in substantial proportions of cells particularly in acute rheumatic fever. CRP-binding lymphocytes may represent a marker for immunologically committed cells in acute rheumatic fever.
\end{abstract}

\section{INTRODUCTION}

C-reactive protein $(\mathrm{CRP})^{1}$ constitutes a material which exists in low concentrations in normal serum but which is often elevated during the course of acute inflammatory reactions such as infection, trauma, or acute rheumatic fever (1-6). Recent comparative analysis of amino acid sequences as well as electron microscopic structure suggest that CRP may share evolutionary sources with $\mathrm{Cl}^{\mathrm{t}}$ related to the Clq component of complement (7). Previous reports by Mortensen et

Received for publication 21 July 1977 and in revised form 13 January 1978.

${ }^{1}$ Abbreviations used in this paper: CRP, C-reactive protein; EA, erythrocyte antibody. al. (8-10) have indicated that CRP may bind to lymphocytes and in particular, may actually adhere to $\mathrm{T}$ cells activated by antigens but not by mitogens such as phytohemagglutinin. Our previous studies have indicated a marked increase in proportions of "active" rosette-forming $T$ cells among children with acute rheumatic fever (11). It was not clear whether active (or rapid) rosette-forming cells constituted a population of immunologically activated $\mathrm{T}$ cells that somehow increased during the acute rheumatic process. Recent reports have related increments in proportions of active T-cell rosettes related to delayed type hypersensitivity reactions after in vivo skin testing (12). Previous studies had appeared to indicate that proportions or numbers of active rosettes might correlate with immune competence $(13,14)$. The purpose of the present study was to examine lymphocyte subpopulations in acute rheumatic fever patients with particular attention to what distinct populations of lymphocytes showed CRP binding. It was felt that such cells might represent immunologically committed or possibly antigen-activated cells called forth in the host response to the disease process.

\section{METHODS}

Patients studied. 31 patients with acute rheumatic fever were studied during the first 3 wk of April 1977. All of the patients were hospitalized at the Free Rheumatic Heart Center in Cairo, Egypt $(11,15)$, and were between the ages of 3 and 14 with active acute rheumatic fever. The diagnosis was established using the modified Jones Criteria as suggested by the American Heart Association (16). The majority of patients studied were subjects in the relatively acute stages of rheumatic pancarditis, 1-8 wk after the onset of symptoms. Of these patients, 11 were experiencing their first attack, whereas the other 20 children were studied in an exacerbation having had two to seven previous episodes of carditis or active chorea. 10 patients with acute chorea and associated carditis, or evidence on physical examination of active mitral valve involvement were included in the study; the remainder were studied during the progress of active carditis. 
9 of the 21 patients with active carditis had received corticosteroids as therapy for their flagrant carditis. Concurrent dosage of prednisone ranged from 5 to $30 \mathrm{mg} /$ day. Nine patients with active carditis were also studied who were receiving salicylates alone, and three were studied before the administration of any therapy. The 10 patients with chorea were receiving salicylates as well as reserpine preparations and phenobarbital for the control of their movement disorder.

The average age of patients with carditis was 9.1 years ( 13 females and 8 males). The chorea patients averaged 10.3 years of age ( 8 females and 2 males).

Six normal control subjects were studied from control Egyptian children hospitalized at Cairo University Hospital on the general pediatric service for correction of congenital deformities or treatment of noninflammatory conditions. In addition, a group of 24 normal children, ages 5-15 and matched for age and sex, were studied in Egypt and Albuquerque.

Special studies. CRP was determined in serum samples using radial diffusion and the technique of Kindmark (17), and all results expressed as nanograms per deciliter of serum. Serum samples which could not be used for CRP determination because of the limits of sensitivity of the radial diffusion method were assayed using the radioimmunoassay modified slightly from the original technique described by Claus et al. (6). In this assay, highly purified CRP was labeled with ${ }^{131}$ I using the Bolton-Hunter reagent. Labeled CRP was repurified after labeling by elution from C-polysaccharide columns to insure specificity and biologic reactivity. The range of values for normal serum ( 50 samples) was similar to that previously recorded $(60-8,000 \mathrm{ng} / \mathrm{dl})(6)$. Serum samples assayed in parallel by the modified radial diffusion assay and radioimmunoassay, generally showed good agreement with not more than a $15 \%$ difference when the two methods were run in parallel on the same samples.

Lymphocytes were isolated from 12-ml samples of heparinized blood using Ficoll-Hypaque and gradient separation (18). After harvesting the lymphocytes from the gradient, mononuclear cells were depleted of adherent cells and monocytes using adherence to glass petri dishes at $37^{\circ} \mathrm{C}$ for 30 min (19). This $37^{\circ} \mathrm{C}$ incubation also served to allow shedding of adherent immunoglobulin, thus depleting cell surfaces of the latter as noted by Horwitz et al. (20). Nonadherent cells were then utilized for assay of CRP binding. In preliminary assays, whole mononuclear cell preparations in which adherent cells had not been depleted and adherent cells, recovered from petri dishes by gentle scraping with rubber policeman were studied, to ascertain whether such cells constituted a major fraction showing CRP binding. These experiments did not indicate any appreciable contribution by monocytes or other adherent cells to CRP binding because $<1 \%$ of such cell populations showed surface CRP.

CRP binding to lymphocytes utilized two parallel techniques. CRP antisera made in rabbits were obtained from N. L. Cappel Laboratories Inc., Cochranville, Pa., as well as through generous gifts from Dr. Osmand and Dr. Gewurz, Department of Immunology, Rush Medical College, Chicago, Ill., and later from Dr. E. Gotschlich, Rockefeller University, New York. In view of a recent report indicating that antiCRP reagents might show inadvertent specificity for $P$ component as described by Pepys et al. (22), anti-CRP antiserum was tested for possible anti-P specificity using $P$ component affixed to Sepharose $4 \mathrm{~B}$ beads (Pharmacia Fine Chemicals Inc., Uppsala, Sweden) in the presence of calcium ions (23). Sepharose $4 \mathrm{~B}$ beads coated with $\mathrm{P}$ component were strongly positive with specific anti-P-component antiserum but negative with our anti-CRP antisera. These experiments ruled out inadvertent specificity for $\mathrm{P}$ component in the antisera used. All anti-CRP antisera used in the cell-surface marker studies showed complete absorption of activity in the systems studied using CRP isolated from capsular (Cs) polysaccharide columns (8) and freed of contaminants by subsequent gel filtration. IgG fractions from rabbit anti-CRP antiserum were digested by pepsin as previously described (21) to obtain $F\left(a b^{\prime}\right)_{2}$ fragments and were then labeled with either fluorescein or rhodamine. Such labeled $\mathrm{F}\left(\mathrm{ab}^{\prime}\right)_{2}$ preparations showed $F / P$ ratios ranging between 1.5 and 2.0. Completeness of pepsin digestion was assayed using inhibition of precipitation between rabbit $F_{c}$ and specific goat antirabbit $\mathrm{Fc}_{\mathrm{c}}$ antiserum in agar gel and by acrylamide gel electrophoresis. In several instances, pepsin-digested material was also absorbed with whole Cowan I protein A-containing Staphyloccus aureus to insure removal of whole IgG or material containing $F_{C}$ determinants. Mononuclear cell preparations were incubated with fluorescein-labeled $\mathrm{F}\left(\mathrm{ab}^{\prime}\right)_{2}$ of antiCRP and, after washing and resuspension, examined under the Zeiss fluorescence microscope using epifluorescence, a mercury HBO $200 \mathrm{~W}$ lamp with BG 12 primary filter, 53 Barrier filter, and the fluorescein isothiocynate filter (Carl Zeiss, Inc., New York). Double labeling for CRP and other cell surface markers employed fluorescein-labeled aggregates of IgG to detect $F_{C}$ receptors $(11,24)$ in conjunction with rhodaminelabeled $F\left(a b^{\prime}\right)_{2}$ fragments of anti-CRP. In addition, erythrocyte antibody (EA) rosettes prepared from bovine cells coated with optimal sensitizing dilution of isolated rabbit anti-bovine IgG were also used for the detection of $F_{c}$ receptor-bearing cells (25). IgG, coating bovine erythrocytes, was titered to provide a plateau of optimal dilution for producing reproducible $F$ c receptor rosettes. Preliminary studies were conducted to determine whether cells binding fluoresceinlabeled aggregates were identical to those bearing $\mathrm{Fc}_{\mathrm{c}}$ receptors as detected by the IgG sensitized ox-cell technique. Comparative data illustrating these findings are presented in Table I. It can be seen that virtually all the cells showing Fc receptor-binding fluorescent aggregates were eliminated after removal by the rosetting of cells binding to ox cells sensitized with rabbit IgG. Since these experiments utilized lymphocyte populations already depleted of monocytes and previously incubated at $37^{\circ} \mathrm{C}$ to allow for shedding of cytophilic Ig on $\mathrm{L}$ cells, $\mathrm{Fc}$ receptor-bearing cells detected by these techniques constituted $\mathrm{T}$ cells bearing $\mathrm{Fc}$ receptors, $B$ cells, and possibly $L$ cells with $F_{c}$ receptors. Doublelabeling experiments were also conducted on cells showing Fc receptors either by $\mathrm{EA}$ or fluorescent aggregate-binding technique. This was performed using rhodamine-conjugated goat anti-human IgG. In all experiments given in Table I, cells showing EA or positive fluorescent aggregate binding showed no more than 1-2\% concordance with cells bearing surface Ig as detected by rhodamine labeled goat anti-human IgG. In many instances, simultaneous double labeling of cells utilized incubation of fluorescein or rhodamine $F\left(a b^{\prime}\right)_{2}$ antiCRP and formation of EA rosettes.

The second parallel technique used for detecting lymphocytes bearing CRP utilized Cowan I strain of $S$. aureus containing surface protein $\mathrm{A}$ and suspensions of lightly formalinized bacteria. Such suspensions could be stored at $4^{\circ} \mathrm{C}$ for $2-3$-wk periods with retention of equivalent activity as indicator particles in the assay (26).

Suspensions of bacteria standardized at uniform optical density (560) in the Coleman spectrophotometer (Coleman Systems, Irvine, Calif.) were utilized. 50 $\mu \mathrm{l}$ of anti-CRP was added to $5 \times 10^{6}$ lymphocytes in $0.25 \mathrm{ml}$ of minimal essential medium, pH 7.4 plus $10 \%$ fetal calf serum. After being washed twice in the medium, $50 \mu \mathrm{l}$ of standard bacterial suspension was added, the volume was brought to $2.5 \mathrm{ml}$, and the mixture was then centrifuged at $1,000 \mathrm{~g}$ to remove nonadherent bacteria. Lymphocyte suspensions were gently distributed on 
TABLE I

Relative Percentages of Whole Unfractionated Lymphocytes Bearing Fc Receptors for IgG Using Parallel and Simultaneous Assays

\begin{tabular}{cccccc}
\hline $\begin{array}{c}\text { Patient } \\
\text { studied }\end{array}$ & $\begin{array}{c}\text { Fc Receptors } \\
\text { by fluorescent } \\
\text { aggregates }\end{array}$ & $\begin{array}{c}\text { Cells with Fc } \\
\text { receptors also positive } \\
\text { for surface Ig }\end{array}$ & $\begin{array}{c}\text { Fc Receptors } \\
\text { by EA ox cell } \\
\text { rosettes }\end{array}$ & $\begin{array}{c}\text { Cells forming } \\
\text { EA also positive } \\
\text { for surface Ig }\end{array}$ & $\begin{array}{c}\text { Cells showing fluorescence } \\
\text { with labeled aggregates } \\
\text { after EA ox cell depletion }\end{array}$ \\
\hline & $\%$ & $\%$ & $\%$ & $\%$ & $\%$ \\
1 & 8 & 0 & 12 & 1 & 0 \\
2 & 9 & 1 & 14 & 1 & 0 \\
3 & 10 & 2 & 12 & 2 & 0 \\
4 & 8 & 1 & 14 & 1 & 1 \\
5 & 11 & 2 & 13 & 1 & 0 \\
\hline
\end{tabular}

glass slides, fixed with absolute methyl alcohol, and stained with Wright's-Giemsa stain. Lymphocytes binding CRP were then identified by counting 200 cells. Controls included cells coated with normal rabbit serum as well as cells and bacteria alone.

Before use in the respective assays, anti-CRP antiserum as well as normal rabbit sera were absorbed with lymphocytes using $10 \times 10^{6}$ cells per $\mathrm{ml}$ of serum. Background controls with normal rabbit serum or bacteria and cells alone never showed $>1 \%$ apparent binding.

Specificity for both the indirect immunofluorescence as well as $S$. aureus protein A methods was tested by absorption of anti-CRP antisera with highly purified preparations of human CRP prepared from pneumococcal C-polysaccharide immunoabsorbent columns and CRP-rich pleural or ascitic fluids as previously described by Mortensen et al. (8).

Cell subpopulation separation. Cells depleted of monocytes or adherent cells were passed over Ig-anti-IgG Degalan columns to further deplete cells of those bearing surface Ig $(19,21)$. Cells were studied for CRP binding before and after such column passage.

In addition, the technique of Moretta et al. $(27,28)$ was utilized in an attempt specifically to prepare $T$ cells bearing $\mathrm{Fc}$ receptors for IgM as well as those with receptors for $\mathrm{Fc}_{\mathrm{C}}$ of IgG. This technique utilized enrichment for T-cell rosetting cells with neuraminidase-treated sheep erythrocytes followed by overnight incubation in $5 \% \mathrm{CO}_{2}$ air at $37^{\circ} \mathrm{C}$ in Hanks' balanced salt solution. Cells undergoing this selective $T$-cell enrichment and overnight shedding were then examined for $\mathrm{T}$ cells bearing IgM $(\mathrm{T} \mu)$ and IgG receptors $(\mathrm{T} \gamma)$ as well as for presence of CRP using direct immunofluorescence and $F(a b)_{2}$ anti-CRP in conjunction with bovine cell rosettes coated with rabbit IgM or IgG. These experiments also served to provide some evidence as to stability of surface binding to CRP.
Attempts were made to determine if active $\mathrm{T}$-cell rosetting cells contained a population capable of binding CRP. In these experiments, active rosettes were prepared as previously described (11), and after rosetting at $1 \mathrm{~h}$, actively rosetting cells were separated on Ficoll-Hypaque and adherent erythrocytes were lysed using $0.83 \%$ ammonium chloride for $10 \mathrm{~min}$ at $37^{\circ} \mathrm{C}$. Cells sedimenting to the bottom of the gradient and, therefore, lymphocytes making active or rapid rosettes, were studied immediately or, in some instances, incubated overnight at $37^{\circ} \mathrm{C}$ in $5 \% \mathrm{CO}_{2}$ air in $20 \%$ fetal calf serum-Eagle's minimum essential medium, and then stained by direct immunofluorescence using $\mathbf{F}\left(\mathrm{ab}^{\prime}\right)_{2}$ fragments of anti-CRP. In parallel, the lymphocytes not forming active rosettes were processed and subsequently examined for immunofluorescent CRP binding.

A final control involved studies of five patients with chronic myelogenous leukemia and eight patients with acute lymphocytic leukemia. Small proportions (1-5\%) of CRP-binding cells in peripheral blood samples from some of these subjects were always associated with $\mathrm{T}$ lymphocytes as monitored by concomitant $E$ rosetting. No binding of CRP was detected with immature granulocytes or blast cells from patients with various forms of leukemia.

\section{RESULTS}

A marked increment in both proportions and total numbers of CRP-binding cells was noted in peripheral blood lymphocytes obtained from patients with acute rheumatic fever when compared with values obtained using normal child controls. These data are presented in Table II. Values for proportions of cells bearing CRP were slightly higher using direct immunofluores-

TABLE II

Lymphocytes Binding CRP in Normal Controls and Children with Acute Rheumatic Fever

\begin{tabular}{|c|c|c|c|c|}
\hline & $\begin{array}{l}\text { CRP-binding } \\
\text { lymphocytes }\end{array}$ & & Total no. of CRP & \\
\hline & $\%$ & & $\begin{array}{c}\text { lymphocytes/ } \\
\mathrm{mm}^{3}\end{array}$ & \\
\hline $\begin{array}{l}\text { Acute rheumatic fever }(30) \\
\text { Normal children controls }(30)\end{array}$ & $\begin{array}{r}16.3 \pm 8.3 \\
3.3 \pm 2.9\end{array}$ & $P<0.0001$ & $\begin{array}{l}821.8 \pm 509.6 \\
137.6 \pm 61.5\end{array}$ & $P<0.0001$ \\
\hline
\end{tabular}


cence and $\mathrm{F}\left(\mathrm{ab}^{\prime}\right)_{2}$ fragments of anti-CRP than those obtained in parallel using the Cowan I binding method. However, in general, excellent agreement in values for CRP-binding cells was noted using the two methods in parallel (Table III). Specificity of anti-CRP antiserum used in immunofluorescence and Cowan I $S$. aureus binding was confirmed by absorption using highly purified CRP obtained from C-polysaccharide affinity columns. After such absorption, no positive cells were detected using either method.

Because the high proportions of CRP-binding cells occurred in blood samples obtained from acutely ill subjects many with severe rheumatic pancarditis, it seemed possible that lymphocytes binding CRP might directly reflect the amounts of CRP concurrently present in plasma since CRP is known to be markedly elevated during the acute rheumatic process. No direct relationship was apparent between proportions or total numbers of CRP-binding cells and quantitative estimations of CRP in plasmas collected concurrently in subjects with rheumatic fever or normal children controls. Representative data illustrating this point are given in Table IV. It can be seen that the highest three concentrations of plasma CRP in carditis patients 2 $(550,000 \mathrm{ng} / \mathrm{dl}), 7(440,000 \mathrm{ng} / \mathrm{dl})$, and $5(305,000 \mathrm{ng} /$ dl), were associated with 795,993 , and 624 CRP cells/ $\mathrm{mm}^{3}$, respectively, whereas in two chorea patients, 12 and 14, much lower plasma concentrations of CRP $(640 \mathrm{ng} / \mathrm{dl}$ and 3,700 $\mathrm{ng} / \mathrm{dl})$ were associated with 1,247 and $853 \mathrm{CRP}$ cells $/ \mathrm{mm}^{3}$. In addition, a series of overnight incubations were performed and cells were reexamined after a $12-15-\mathrm{h}$ incubation at $37^{\circ} \mathrm{C}$ in $5 \%$

TABLE III

Representative Determinations Using Immunofluorescence and Cowan I S. Aureus Methods for Determination of CRP-Binding Lymphocytes

\begin{tabular}{|c|c|c|c|}
\hline \multicolumn{2}{|c|}{ Patient studied } & \multicolumn{2}{|c|}{ CRP-binding cells } \\
\hline Patient no. & Condition & Immunofluorescence & S. aureus binding \\
\hline & & & \\
\hline 85 & Carditis & 9 & 5 \\
\hline 70 & Carditis & 19 & 12 \\
\hline 63 & Carditis & 35 & 28 \\
\hline 73 & Carditis & 28 & 24 \\
\hline 64 & Carditis & 14 & 10 \\
\hline 30 & Carditis & 8 & 10 \\
\hline 49 & Carditis & 13 & 10 \\
\hline 329 & Carditis & 5 & 6 \\
\hline 93 & Carditis & 10 & 11 \\
\hline 92 & Chorea & 18 & 10 \\
\hline 83 & Chorea & 23 & 24 \\
\hline 75 & Chorea & 32 & 24 \\
\hline 154 & Chorea & 11 & 11 \\
\hline 69 & Chorea & 13 & 10 \\
\hline
\end{tabular}

TABLE IV

Relationship between Numbers and Proportions of CRPBinding Lymphocytes and ()uantitative Estimations of Plasma CRP

\begin{tabular}{|c|c|c|c|}
\hline Patient no. & $\begin{array}{l}\text { CRP-binding } \\
\text { cells }\end{array}$ & $\begin{array}{l}\text { Absolute no. of } \\
\text { CRP-binding cells }\end{array}$ & Plasma CRP \\
\hline & $\%$ & & $n g / d l$ \\
\hline \multicolumn{4}{|l|}{$\begin{array}{l}\text { Rheumatic } \\
\text { carditis }\end{array}$} \\
\hline 1 & 9 & 314 & 2,050 \\
\hline 2 & 19 & 79.5 & 550,000 \\
\hline 3 & 32 & 1,442 & 3,100 \\
\hline 4 & 35 & 2,041 & 125,000 \\
\hline 5 & 28 & 624 & 305,000 \\
\hline 6 & 27 & 2,547 & 265,000 \\
\hline 7 & 17 & 993 & 440,000 \\
\hline 8 & 14 & 464 & 3,650 \\
\hline 9 & 8 & 509 & 115,000 \\
\hline 10 & 8 & 494 & 2,050 \\
\hline \multicolumn{4}{|l|}{ Chorea } \\
\hline 11 & 18 & 753 & 240,000 \\
\hline 12 & 28 & 1,247 & 640 \\
\hline 13 & 23 & 1,269 & 3,850 \\
\hline 14 & 32 & 853 & 3,700 \\
\hline 15 & 13 & 593 & 2,050 \\
\hline \multicolumn{4}{|l|}{$\begin{array}{l}\text { Normal } \\
\text { controls }\end{array}$} \\
\hline 1 & 2 & 156 & 56,000 \\
\hline 2 & 2 & 147 & 4,000 \\
\hline 3 & 3 & 140 & 1,170 \\
\hline 4 & 4 & 206 & 640 \\
\hline 5 & 2 & 74 & 1,050 \\
\hline 6 & 1 & 48 & 3,900 \\
\hline 7 & 3 & 8.5 & 750 \\
\hline 8 & 4 & 150 & 3,200 \\
\hline 9 & 2 & .52 & 3,350 \\
\hline 10 & 2 & 100 & 1,050 \\
\hline
\end{tabular}

$\mathrm{CO}_{2}$ air incubator. Of great interest was the apparent persistence and, in some instances, slight increase in proportions of CRP-binding cells after such incubation. Examples of such representative experiments using acute rheumatic fever subjects' cells as well as normal controls are shown in Fig. 1. Cell viability as measured by trypan blue exclusion remained between 9.5 and $98 \%$ after such incubations. It was clear that lymphocytes binding CRP did not undergo extensive elution under the circumstances of incubation, although in some instances a slight decrease or increase in proportions of CRP-binding cells was apparent. In the case of experiments where slight increments in proportions of CRP-binding cells were noted after overnight incubation, immunoassay of the supernates did not provide any clear evidence for synthesis of CRP by cultured lymphoid cells.

If, as originally suggested by Mortensen et al. (8-10), 


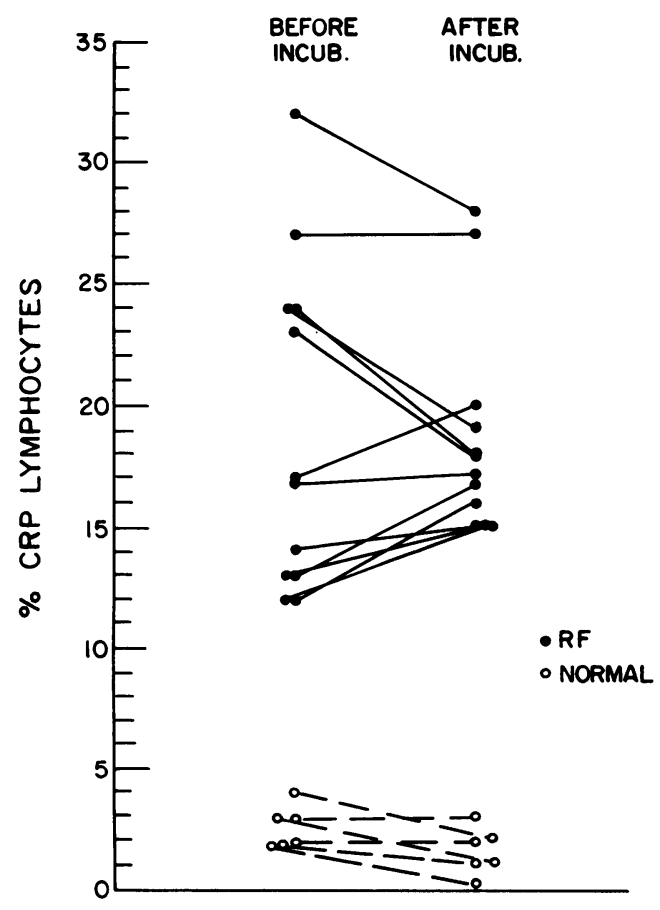

FIGURE 1 Results of changes in proportions of CRP-bearing cells as identified using fluorescein-labeled $\mathrm{F}\left(\mathrm{ab}^{\prime}\right)_{2}$ fragments of anti-CRP before and after $12-15$-h incubations at $37^{\circ} \mathrm{C}$ in $5 \% \mathrm{CO}_{2}$-air incubator. $\mathrm{RF}$, rheumatic fever.

CRP-binding cells represent antigen-activated $\mathrm{T}$ cells, their concomitant cell-surface markers might provide an indication as to what lymphocyte subpopulations were actually involved in such a process during the rheumatic fever episode. Accordingly, a variety of double-labeling experiments focused on this particular point. Among unfractionated lymphocytes depleted of monocytes and adherent cells, about one-half of all the cells reacting with fluorescein-conjugated aggregates showed concurrent staining for rhodamine-conjugated $\mathrm{F}\left(\mathrm{ab}^{\prime}\right)_{2}$ fragments of anti-CRP. Representative experiments illustrating these findings are provided in Table Va. Cells showing staining for both CRP and human aggregated IgG showed distinct and separate immunofluorescence. Thus, the staining for rhodamine-labeled anti-CRP appeared as red fluorescent spots and patches clearly distinct from the apple-green particulate surface immunofluorescence produced by the $F_{c}$ receptor adherence to isothiocyanate-labeled IgG aggregates. Observation of cells after incubation at $37^{\circ} \mathrm{C}$ for $30-$ $60 \mathrm{~min}$ showed a tendency for polarity or capping of anti-CRP-binding structures which was clearly separate from $F_{C}$ receptors identified with the fluorescent green IgG aggregates. However, endocytosis and disappearance of CRP was not observed after observations up to $3 \mathrm{~h}$. From these experiments, it was apparent that a considerable proportion of CRP-binding cells were lymphocytes which showed IgG Fc receptors.
A further attempt to define lymphocyte subpopulations bearing CRP was performed using Ig-anti-IgG Degalan column passage to deplete surface Ig containing cells. The results obtained after such immunoabsorbent column depletion are given in Table $\mathrm{V} b$. The increase in proportions of CRP-binding cells after Ig-anti-Ig column passage along with virtually complete elimination of cells bearing surface Ig, indicated that B cells with surface immunoglobulin did not constitute a major population showing CRP binding, and that the residual population-presumably mainly $\mathrm{T}$ or $\mathrm{L}$ cells without surface Ig but possessing $\mathrm{Fc}$ receptors $(29,30)$, were largely responsible for surface CRP. To examine these findings further, $\mathrm{Fc}_{\mathrm{c}}$ receptor-bearing cells were specifically enriched for using EA rosette formation with ox cells coated with rabbit IgG antibody and isolation of such rosette-forming cells by Ficoll gradients. Proportions of CRP-binding cells in non-EA rosette-forming lymphocyte cell preparations were compared to those enriched by rosetting for EA Fc receptor bearing cells. Again, as in the case of double-labeling studies described above, it was clear from

TABLE V

Double-Labeling Experiments to Determine Overlap of Cell Surface Markers with Lymphocytes Binding CRP

\begin{tabular}{|c|c|c|c|}
\hline $\begin{array}{c}\text { (A) } \\
\text { Patient studied }\end{array}$ & $\begin{array}{l}\text { Proportion of } \\
\text { cells staining } \\
\text { with fluores- } \\
\text { ceinated IgG } \\
\text { aggregates }\end{array}$ & $\begin{array}{c}\text { Proportion of } \\
\text { cells staining } \\
\text { with pepsin- } \\
\text { digested } \\
\text { anti-CRP } \\
\text { (rhodamine- } \\
\text { labeled) }\end{array}$ & $\begin{array}{c}\text { Proportion } \\
\text { of cells } \\
\text { showing } \\
\text { double } \\
\text { staining }\end{array}$ \\
\hline & $\%$ & $\%$ & $\%$ \\
\hline 82, Carditis & 14 & 11 & 7 \\
\hline 5105, Chorea & 14 & 15 & 9 \\
\hline 329, Carditis & 28 & 16 & 13 \\
\hline \multicolumn{4}{|c|}{$\begin{array}{c}\text { Experiments before and After Passage of Cells } \\
\text { over Ig-Anti-Ig Degalan Columns }\end{array}$} \\
\hline $\begin{array}{l}(B) \\
\text { Patient studied }\end{array}$ & $\begin{array}{l}\text { Proportion of } \\
\text { cells staining } \\
\text { with pepsin- } \\
\text { digested } \\
\text { anti-CRP }\end{array}$ & $\begin{array}{l}\text { Proportion of } \\
\text { cells with } \\
\text { complement } \\
\text { receptor } \\
\text { EAC }\end{array}$ & $\begin{array}{l}\text { Proportion } \\
\text { of cells } \\
\text { showing } \\
\text { surface } \\
\text { Ig* }\end{array}$ \\
\hline & $\%$ & $\%$ & $\%$ \\
\hline $\begin{array}{l}106 \text { Before } \mathrm{Ig}-\mathrm{a} \\
\text { column }\end{array}$ & 23 & 30 & 25 \\
\hline $\begin{array}{l}\text { After Ig-anti-Ig } \\
\text { column }\end{array}$ & 40 & 5 & 1 \\
\hline $\begin{array}{l}114 \text { Before } \mathrm{Ig}-\mathrm{a} \\
\text { column }\end{array}$ & 17 & 0 & 23 \\
\hline $\begin{array}{l}\text { After Ig-anti-Ig } \\
\text { column }\end{array}$ & 24 & 0 & 0 \\
\hline
\end{tabular}

* Cells with surface Ig identified using fluorescein-labeled $\mathrm{F}\left(\mathrm{ab}^{\prime}\right)_{2}$ fragments of rabbit anti-human Ig. 
TABLE VI

Relative Proportions and Total Numbers of T-Cell Subpopulations in Patients with Rheumatic Carditis or Chorea and Normal Controls

\begin{tabular}{|c|c|c|c|c|c|c|c|}
\hline Patient group & \multicolumn{3}{|c|}{$T$ cells bearing receptors for $F_{c} \operatorname{IgG}(T \gamma)$} & & \multicolumn{3}{|c|}{$\mathrm{T}$ cells bearing receptors for $\mathrm{FC}_{\mathrm{C}} \operatorname{IgM}(\mathrm{T} \mu)$} \\
\hline Normal controls $(30)$ & $10.5 \pm 4.5^{*}$ & $P<001$ & $313.1 \pm 184.5$ & $P<001$ & $49.5 \pm 10.4$ & $P<001$ & $1,577 \pm 721.6 \ddagger$ \\
\hline Rheumatic fever and carditis (16) & $15.9 \pm 6.6$ & $P<0.01$ & $811.4 \pm 742.4\}$ & $P<0.01$ & $33.4 \pm 10.3$ & $P<0.01$ & $1,654.9 \pm 1,348$ \\
\hline Rheumatic fever and chorea (8) & $10.9 \pm 3.5$ & & $392.8 \pm 148.5$ & & $30.1 \pm 7.3$ & & $1,158.1 \pm 560 \ddagger$ \\
\hline
\end{tabular}

* Numbers refer to mean \pm SD.

$\ddagger$ Difference between absolute no. of lymphocytes bearing Fc IgM receptors NS.

several experiments that $\mathrm{Fc}_{\mathrm{c}}$ receptor-bearing cells and CRP binding were occurring together. In these experiments, cell populations specifically enriched for lymphocytes bearing $\mathrm{Fc}_{\mathrm{c}}$ receptors in four experiments showed 21-25\% concurrent double labeling for CRP. However, fluorescence CRP identification in the presence of concurrent EA rosettes was technically judged more difficult.

During various physiologic states, particularly those related to activation, $\mathrm{T}$ cells are known to show $\mathrm{Fc}$ receptors $(31,32)$. Accordingly, a series of experiments which focused on specific $\mathrm{T}$-cell populations were conducted. T cells bearing specific IgM or IgG Fc receptors were prepared by the techniques of Moretta et al. $(27,28)$. Results of $\mathrm{T} \mu$-and $\mathrm{T} \gamma$-cell determinations on children with acute rheumatic fever as well as normal controls are given in Table VI. It was clear that $\mathrm{T} \mu$ cells predominated and that $\mathrm{T} \gamma$ cells constituted only a small fraction of the total $\mathrm{T}$ cells that were specifically enriched by neuraminidase sheep cell rosetting and overnight incubation to allow shedding and membrane stabilization. Of interest were the findings of significant elevation of proportions and numbers of $\mathrm{T} \gamma$ cells in rheumatic children with decrease in proportions of $\mathrm{T} \mu$ cells as compared to controls. After isolation of $\mathrm{T}$ cells using rosetting with neuraminidase- treated sheep erythrocytes and overnight incubation at $37^{\circ} \mathrm{C}$ in IgM-free medium, concurrent labeling of $\mathrm{T} \mu$ and $\mathrm{T} \gamma$ cells was performed using fluoresceinlabeled $\mathrm{F}\left(\mathrm{ab}^{\prime}\right)_{2}$ fragments of anti-CRP. These parallellabeling experiments showed that no $\mathrm{T} \mu$ cells bearing receptors for Fc of IgM showed CRP binding, whereas 25-60\% (mean 46\%) of $\mathrm{T} \gamma$ cells bearing IgG Fc receptors bound CRP. Thus, when specific T-cell populations were examined for CRP, only T $\gamma$ cells showed surface staining. Representative data illustrating these findings are given in Table VII.

Experiments were also conducted on cells remaining at the Ficoll-Hypaque gradient interface after neuraminidase-rosetting of E-binding $\mathrm{T}$ cells. In five experiments, $12-16 \%$ of cells remaining in this B-cell layer showed CRP binding-even after overnight incubation at $37^{\circ} \mathrm{C}$. Cell surface-marker studies in this presumptive B-cell layer showed $50-65 \%$ cells with surface Ig and 20-26\% cells with $\mathrm{Fc}_{\mathrm{c}}$ receptors by bovine EA rosettes. In two experiments where enough cells were present for accurate double-labeling studies on these isolated B cells after overnight incubation, 40 and $38 \%$ showed concurrent binding of pepsin-digested fluorescein-labeled anti- $\mathrm{F}\left(\mathrm{ab}^{\prime}\right)_{2}$ and rhodaminelabeled $\mathrm{F}\left(\mathrm{ab} \mathrm{b}^{\prime}\right)_{2}$ of anti-CRP. This clearly established that there was a definite overlap between cells bearing

TABLE VII

CRP-Binding T-Cell Populations in Acute Rheumatic Fever

\begin{tabular}{|c|c|c|c|c|c|c|c|}
\hline \multicolumn{2}{|c|}{ Patient studied } & \multirow{2}{*}{$\begin{array}{l}\text { Unfractionated } \\
\text { lymphocytes } \\
\text { binding CRP* }\end{array}$} & \multirow{2}{*}{$\begin{array}{l}\text { Total isolated } \\
\text { T cells positive } \\
\text { for CRP* }\end{array}$} & \multirow[b]{2}{*}{$\mathrm{T} \gamma$ cells } & \multirow[b]{2}{*}{$\mathrm{T} \gamma+\mathrm{CRP}^{*}$} & \multirow[b]{2}{*}{$\mathrm{T} \mu$ cells } & \multirow[b]{2}{*}{$\mathrm{T}_{\mu}+\mathrm{CRP}^{*}$} \\
\hline $\begin{array}{c}\text { Patient } \\
\text { no. }\end{array}$ & Condition & & & & & & \\
\hline & & $\%$ & $\%$ & $\%$ & $\%$ & $\%$ & $\%$ \\
\hline 73 & Acute carditis & 26 & 12 & 16 & 25 & 20 & 0 \\
\hline 92 & Chorea & 18 & 20 & 10 & 40 & 37 & 0 \\
\hline 56 & Chorea & 28 & 17 & 13 & 50 & 37 & 0 \\
\hline 65 & Carditis & 24 & 20 & 23 & 60 & 47 & 0 \\
\hline 83 & Chorea & 26 & 18 & 12 & 58 & 35 & 0 \\
\hline
\end{tabular}

* Unfractionated cells and isolated $\mathrm{T}$ cells studied by indirect immunofluorescence using $\mathrm{F}\left(\mathrm{ab}^{\prime}\right)_{2}$ anti-CRP. 
surface Ig and those capable of binding CRP. In addition, double-labeling experiments using EA rosettes and anti-CRP $\mathrm{F}\left(\mathrm{ab}^{\prime}\right)_{2}$ showed concomitant occurrence of these surface markers in 40 and $52 \%$ of isolated Bcell fractions. T-cell contamination as monitored by $\mathrm{E}$ rosettes was $<2 \%$. These data are given in Table VIII.

Experiments were next designed to examine whether active rosette-forming cells participated in CRP binding. Very little overlap in these two populations occurred. Separation of active or rapid rosette-forming cells and comparison with remaining whole lymphocyte populations either immediately before or after 12 14-h incubations at $37^{\circ} \mathrm{C}$ showed that very few $\left(0_{-}\right.$ $1 \%$ ) of the active rosette-forming cells bound CRP. By contrast, a considerable fraction of cells which did not form early rosettes were shown to bind CRP (Table IX). Subsequent double-labeling experiments with this latter population again confirmed the presence of frequent concurrent $F_{C}$ receptors and CRP binding in cells not participating in active $\mathrm{T}$-cell rosette formation.

\section{DISCUSSION}

The current findings indicate that a marked increase in cells binding CRP occurs during the course of acute rheumatic fever. This was demonstrated using two, parallel independent methods of lymphocyte-CRP binding, which included direct immunofluorescent la-

TABLE VIII

Studies of CRP Binding in Unfractionated and Isolated Lymphocyte Populations in Patients with Acute Carditis of Rheumatic Fever

\begin{tabular}{|c|c|c|c|c|c|c|}
\hline \multirow{2}{*}{\multicolumn{2}{|c|}{ Patient studied }} & \multirow{3}{*}{$\begin{array}{l}\text { Unfrac- } \\
\text { tionated } \\
\text { lympho- } \\
\text { cytes } \\
\text { binding } \\
\text { CRP }\end{array}$} & & & \multicolumn{2}{|c|}{$\begin{array}{l}\text { Double-labeling } \\
\text { methods on B-cell } \\
\text { fraction }\end{array}$} \\
\hline & & & \multicolumn{2}{|c|}{ CRP binding } & \multirow{2}{*}{$\begin{array}{l}\text { Cells } \\
\text { showing } \\
\text { surface } \\
\text { Ig plus } \\
\text { CRP }\end{array}$} & \multirow{2}{*}{$\begin{array}{l}\text { Cells } \\
\text { showing } \\
\text { EA } \\
\text { rosette } \\
\text { plus CRP }\end{array}$} \\
\hline \multirow[t]{2}{*}{ No. } & Condition & & cells* & cells & & \\
\hline & & $\%$ & \multicolumn{2}{|c|}{$\%$} & \multicolumn{2}{|c|}{$\%$} \\
\hline 103 & $\begin{array}{l}\text { Acute } \\
\text { carditis }\end{array}$ & 14 & 7 & 8 & 38 & 40 \\
\hline 108 & $\begin{array}{l}\text { Acute } \\
\quad \text { carditis }\end{array}$ & 16 & 7 & 11 & 40 & 52 \\
\hline
\end{tabular}

* $\mathrm{T}$ cells isolated by neuraminidase $\mathrm{E}$ rosetting and allowed to shed or incubate in $5 \% \mathrm{CO}_{2}$-air at $37^{\circ} \mathrm{C}$ in medium for $12 \mathrm{~h}$. $\$ \mathrm{~B}$ cells refer to the cells not separated by Ficoll-Hypaque as neuraminidase rosette-forming cells, but remaining at Ficoll-Hypaque interface. Cell-surface marker studies on these cell fractions showed 50-65\% cells with surface Ig and $20-26 \%$ cells with $F_{c}$ receptors by bovine EA rosette formation.
TABLE IX

Rapid Rosette-Forming Cells and Nonrapid Rosetting Cells Double-Labeled for CRP

\begin{tabular}{ccc}
\hline & \multicolumn{2}{c}{ Binding CRP } \\
\cline { 2 - 3 } $\begin{array}{c}\text { Patient } \\
\text { studied }\end{array}$ & Rapid rosettes & $\begin{array}{c}\text { Nonrapid rosette-forming } \\
\text { cells }\end{array}$ \\
\hline & $\%$ & $\%$ \\
1 & 2 & 14 \\
2 & 0 & 24 \\
4 & 0 & 17 \\
4 & 0 & 15 \\
\hline
\end{tabular}

beling of cells using $\mathrm{F}\left(\mathrm{ab}^{\prime}\right)_{2}$ fragments of anti-CRP as well as binding of Cowan I S. aureus bacteria coated with anti-CRP through $\mathrm{Fc}$-reactive sites on protein A of the staphlococcus. Use of pepsin-digested $F\left(a b^{\prime}\right)_{2}$ fragments of anti-CRP avoided inadvertent adsorption of reagent to cell surface $F_{c}$ receptors (33). It is possible that other nonimmunologic changes may actually affect lymphocyte-binding to CRP. Availability of enough purified CRP at the time of the work in Cairo prevented studies aimed at this point, utilizing lymphocytes from rheumatic fever children and addition of exogenous CRP after appropriate shedding or incubation. We have, however, confirmed the fact that CRP added to normal lymphocytes does show membrane binding. This does not appear to be a function of $\mathrm{P}$ component and was observed using CRP free of the latter material.

CRP-binding lymphocytes could not be directly correlated with quantitative elevations of plasma CRP since high proportions and total numbers occurred both in patients with elevated as well as much lower quantitative amounts of plasma CRP. It is clear, however, from the data presented in Table IV that some limiting increase in plasma CRP or threshold may be involved in lymphocyte CRP binding. A majority of CRPbinding lymphocytes did not appear to be conventional B cells with surface Ig since depletion of B cells using Ig-anti-IgG columns resulted in relative increase and enrichment of CRP-binding lymphocytes. It must be recognized, however, that such procedures could also have depleted adherent $T$ cells and other cells besides those with surface Ig. When isolated B cells were studied, however, a definite proportion $(38-40 \%)$ showed concordance between CRP and cell surface Ig using $\mathrm{F}\left(\mathrm{ab}^{\prime}\right)_{2}$ reagents. Several approaches at double labeling showed that CRP-binding cells often occurred in association with cell surface IgG $F_{c}$ receptors. In addition, studies of cell populations enriched for $\mathrm{T}$ cells by neuraminidase-sheep cell rosetting and subsequent overnight incubation showed that $\mathrm{T} \mu$ cells did not bind CRP, but that about one-half of $\mathrm{T} \gamma$ cells were associated with CRP binding. Thus, the CRP-binding 
lymphocytes in rheumatic fever represent a definite proportion of B cells, but appear to be mainly associated with presence of cell surface receptors for Fc of IgG. Our findings in children with acute rheumatic fever are somewhat different from the CRP binding primarily to $\mathrm{T}$ cells in normal peripheral blood initially reported by Mortensen et al. $(8,9)$. Data shown in Table VIII indicate some binding to $\mathrm{B}$ cells as well as $\mathrm{T}$ cells in the subjects studied. It seems possible that CRP may bind to lymphocytes in diseased patients perhaps on a different basis from those of normal subjects. It is conceivable that CRP binding may, instead of reflecting an immunological mechanism, merely be related to lymphocyte membrane damage of some kind. Some of the cells bearing $F_{c}$ receptors and CRP appear to be T $\gamma$ cells as defined by Moretta et al. (28). From the data currently available, it appears possible that other lymphocytes bearing $F_{c}$ receptorsperhaps similar to $\mathrm{L}$, null, or $\mathrm{K}$ cells (30) - may also bind CRP. Experiments are now in progress to define this possibility, using CRP-binding cells in an antibody-mediated cytotoxicity system $(34,35)$. CRP-binding cells did not overlap with $\mathrm{T}$ cells forming active rosettes. These findings appear to confirm recent observations by West et al. $(36,37)$ showing that cells active in $\mathrm{T}$-cell rosette formation at temperatures of $32^{\circ} \mathrm{C}$ do not overlap with $\mathrm{T}$ cells bearing $\mathrm{F}_{\mathrm{C}}$ receptors.

If CRP-binding cells actually represent in part antigen-activated $\mathrm{T}$ cells, then such cells could provide an interesting possible source of cells activated towards streptococcal products or possibly cross-reacting cardiac antigens. Our current work has been specifically directed at this possibility. The use of anti-CRP affinity columns as a method to isolate CRP-binding cells and to study their specific reactions to mitogens as well as to a variety of streptococcal or cardiac antigens could provide direct data on whether or not such CRP-binding cells are indeed activated by identifiable antigens. The stability of CRP binding in lymphocytes incubated for $12-15$-h periods is of considerable interest in this regard. Since data in Table VIII indicated that a proportion of CRP-binding cells appeared to bind to cells with $\mathrm{Fc}_{\mathrm{c}}$ receptors which were not $\mathrm{T}$ cells as separated by neuraminidase rosetting, it is also possible that such cells might function as nonspecific effector cells in such systems as natural killing as described by Nelson et al. $(38,39)$.

CRP elevation is known to accompany many acute or subacute inflammatory conditions $(1-6,40,41)$. The exact origin or sites of CRP synthesis as well as localization within inflammatory tissue previously have been studied by several groups $(42-46)$. It is well known that marked CRP elevation in serum accompanies the acute process in rheumatic fever (4). No precise definition of the role of CRP in such disorders as acute rheumatic fever has yet been identified. Be- cause of its elevation in so many inflammatory reactions, CRP has long been regarded merely as an acutephase reactant similar perhaps to other serum proteins of this type such as ceruloplasmin, haptoglobin, or seromucoid $(41,47,48)$. It is clear that CRP is present in small amounts in normal human serum (6) so that its presence does not necessarily reflect synthesis of an abnormal protein. The following hypothesis might be suggested by our own data as well as the previous reports of Mortensen et al. (8-10). If CRP is indeed capable of preferential binding to antigen-activated $\mathrm{T}$, $\mathrm{K}$, or natural killer cells, it is conceivable that such CRP binding might serve to defuse or attenuate selfdirected cellular responses possibly harmful to the host.

The studies involving attempts to determine possible lymphocyte subpopulations binding to CRP bear some comment. Double-labeling techniques clearly indicated that a substantial proportion of CRP-binding cells were $T$ cells. In addition, when $T$ cells were selectively enriched using the neuraminidase erythrocyte-rosetting technique, $\mathrm{T}$ cells showing $\operatorname{IgG} \mathrm{Fc}$ receptors $(\mathrm{T} \gamma)$ but not those bearing $\operatorname{IgM} \mathrm{Fc}_{\mathrm{C}}$ receptors $(\mathrm{T} \mu)$ were positive for CRP binding. These findings are of considerable interest since $\mathrm{T} \mu$ cells have been suggested as putative markers for helper cells $(49,50)$. In the present study, proportions of $\mathrm{T} \mu$ cells have been noted to be decreased during the acute rheumatic process, whereas $\mathrm{T} \gamma$ cells were significantly increased. However, T cells binding CRP clearly appeared also to have $\operatorname{IgG~} \mathrm{Fc}_{\mathrm{c}}$ receptors. Whether such $\mathrm{T} \gamma$ cells carry a specific functional role such as suppressor or killer function remains to be determined. Recent data presented by Moretta et al. (50) appear to indicate a suppressor role for $\mathrm{T} \gamma$ cells in some in vitro assay systems involving B-cell activation.

Our studies of CRP in supernates from lymphocyte cultures or merely incubation experiments have not provided clear evidence for active synthesis of CRP by isolated $\mathrm{T}$ cells. These possibilities have been recently pursued in view of the report of extensive sequence homologies between $\mathrm{Cl}^{t}$ and CRP and the Pamyloid component (7). It is important in this regard to point out that $\mathrm{F}\left(\mathrm{ab}^{\prime}\right)_{2}$ fragments obtained from antiCRP antiserum generously provided by Dr. E. Gotschlich showed similar reactivities in the lymphocyte cell surface assays to those obtained from Dr. Osmand and Dr. Gewurz. The antiserum provided by Dr. Gotschlich was prepared against crystallized CRP whereas that obtained from Dr. Osmand and Dr. Gewurz was prepared from affinity column-purified material. Our testing for anti-P-component specificity in anti-CRP antisera proved negative $(22,23)$. If lymphocytes were under certain circumstances capable of CRP synthesis, they might under previous or current evolutionary circumstances be capable of $\mathrm{Cl}^{\mathrm{t}}$ synthe- 
sis as well. However, the vast bulk of evidence clearly implicates the liver as primary site of synthesis for CRP $(42,46)$.

Recent extensive studies (51-57) have described many of the important potential biological effects of CRP both in vitro and in vivo. Previous work has indicated that mixed leukocyte reactions are diminished when non-HLA-compatible lymphocytes from two patients with acute rheumatic fever are studied together in one-way stimulation $(58)$. Gewurz et al. $(8,53)$ have also shown that mixed leukocyte reaction in normal subjects is diminished by CRP. In the latter instance, CRP effect was attributed to modulation of antigenactivated cells in the mixed leukocyte reaction. It now seems important to recognize that proportions of CRPbinding cells may directly influence several expressions of the immune response. These collective findings are of particular interest in the light of current reports indicating that streptococcal antigens produce an altered cell-mediated immune response in patients with acute rheumatic fever (59).

\section{ACKNOWLEDGMENTS}

We are indebted to Dr. H. Gewurz and Dr. A. P. Osmand for providing us with highly purified $\mathrm{C}$ polysaccharide and anti-CRP and helpful discussions during the course of this work. We would also like to thank Dr. E. Gotschlich for generously providing anti-CRP prepared against previously crystallized antigen. We also thank Dr. M. B. Pepys of Hammersmith Hospital, London, for generously providing anti-P-component antisera, P-component-coated Sephadex, and for helpful suggestions. It is a pleasure to acknowledge the excellent tèchnical assistance of Mrs. Jean Montano, and the secretarial help of Mrs. Carol Montman, Mrs. Vohnda Starr, and Ms. Carol Lombardi.

\section{REFERENCES}

1. Tillet, W. S., and T. Francis, Jr. 1930. Serological reactions in pneumonia with a nonprotein fraction from pneumococcus. J. Exp. Med. 52: 561-571.

2. Abernethy, T. J., and O. T. Avery. 1941. The occurrence during acute infections of a protein not normally present in the blood. I. Distribution of the reactive protein in patients' sera and the effect of calcium on the flocculation reaction with the $\mathrm{C}$-polysaccharide of pneumococcus. J. Exp. Med. 73: 173-182.

3. MacLeod, C. M., and O. T. Avery: 1941. The occurrence during acute infections of a protein not normally present in the blood. II. Isolation and properties of the reactive protein. J. Exp. Med. 73: 183-190.

4. Anderson, H. C., and M. McCarty. 1950. Determination of C-reactive protein in the blood as a measure of the activity of the disease process in acute rheumatic fever. Am. J. Med. 8: 445-455.

5. Hedlund, P. 1961. Clinical and experimental studies on C-reactive protein (acute phase protein). Acta. Med. Scand. 169 (Suppl. 361): 7-71.

6. Claus, D., A. P. Osmand, and H. Gewurz. 1976. Radioimmunoassay of human C-reactive protein and levels in normal sera. J. Lab. Clin. Med. 87: 120-128.

7. Osmand, A. P., B. Friedenson, H. Gewurz, R. H. Painter T. Hofman, and E. Shelton. 1977. Characterization of C- reactive protein and the complement subcomponent $\mathrm{Cl}^{t}$ as homologous proteins displaying cyclic pentameric symmetry (pentraxins). Proc. Natl. Acad. Sci. U. S. A. 74: 739-743.

8. Mortensen, R. F., A. P. Osmand, and H. Gewurz. 1975 Effects of C-reactive protein on the lymphoid system. I. Binding to thymus-dependent lymphocytes and alteration of their function. J. Exp. Med. 141: 821-839.

9. Mortensen, R. F., and H. Gewurz. 1974. Specific binding of human C-reactive protein to T-lymphocytes. Clin. Res. 22: 643A. (Abstr.)

10. Croft, S. M., R. F. Mortensen, and H. Gewurz. 1976. Binding of C-reactive protein to antigen-induced but not mitogen-induced T-lymphoblasts. Science (Wash. D. C.). 193: 685-687.

11. Williams, R. C., Jr., J. B. Zabriskie, F. Mahros, F. Hassaballa, and Z. H. Abdin. 1977. Lymphocyte surface markers in acute rheumatic fever and post-streptococcal acute glomerulonephritis. Clin. Exp. Immunol. 27: 135-142.

12. Felsburg, P. J., R. Edelman, and R. H. Gilman. 1976. The active E-rosette test: correlation with delayed cutaneous hypersensitivity. J. Immunol. 116: 1110-1114.

13. Fudenberg, H. H., J. Wybran, and D. Robbins. 1975. Trosette forming cells, cellular immunity, and cancer. $N$. Engl. J. Med. 292: 475-476.

14. Horowitz, S., T. Grashong, R. Albrecht, and R. Hong. 1975. The "active" rosette test in immunodeficiency diseases. Clin. Immunol. Immunopathol. 4: 405-414.

15. Husby, G., I. Van de Rijn, B. Zabriskie, H. Abdin, and R. C. Williams, Jr. 1976. Antibodies reacting with cytoplasm of subthalamic and caudate nuclei in chorea and acute rheumatic fever. J. Exp. Med. 144: 1094-1110.

16. American Heart Association. 1956. Jones criteria (revised) for guidance in the diagnosis of rheumatic fever. Circulation. 32: 664-668.

17. Kindmark, C. O. 1972. Quantitative determination of individual serum proteins by radio-electro-immunoassay and use of ${ }^{125}$ I-labeled antibodies (application to C-reactive protein). Scand. J. Clin. Lab. Invest. 29(Suppl. 124): 49-53.

18. Böyum, A. 1968. Isolation of mononuclear cells and granulocytes from human blood: isolation of mononuclear cells by one centrifugation, and of granulocytes by combining centrifugation and sedimentation at $1 \mathrm{~g}$. Scand. J. Clin. Lab. Invest. 21(Suppl. 97): 77-89.

19. Bankhurst, A. D., and R. C. Williams, Jr. 1975. Identification of DNA-binding lymphocytes in patients with systemic lupus erythematosus. J. Clin. Invest. 56: 13781385.

20. Horwitz, D. A., and P. I. Lobo. 1975. Characterization of two populations of human lymphocytes bearing easily detectable immunoglobulin. J. Clin. Invest. 56: 14641472 .

21. Husby, G., R. G. Strickland, J. L. Caldwell, and R. C. Williams, Jr. 1975. Localization of T- and B-cells and alpha-fetoprotein in hepatic biopsies from patients with liver disease. J. Clin. Invest. 56: 1198-1209.

22. Pepys, M. B., A. C. Dash, E. A. Munn, A. Feinstein, M. Skinner, A. S. Cohen, H. Gewurz, A. P. Osmand, and R. H. Painter. 1977. Isolation of amyloid P component (protein AP) from normal serum as a calcium-dependent binding protein. Lancet. I: 1029-1031.

23. Pepys, M. B., A. C. Dash, and M. J. Ashley. 1977. Isolation of C-reactive protein by affinity chromatography. Clin. Exp. Immunol. 30: 32-37.

24. Dickler, H. B., and H. Kunkel. 1972. Interaction of aggregated $\gamma$-globulin and B lymphocytes. J. Exp. Med. 136: 191-196.

25. Witemeyer, S. B., A. D. Bankhurst, and R. C. Williams, 
Jr. 1977. A population of human cord blood lymphocytes which generates $\mathrm{Fc}$ receptors in vitro. Cell. Immunol. 30: $54-65$.

26. Kearney, R., E. Chia, and A. Basten. 1975. Detection of membrane-associated antigens on lymphoid cells by antibody coupled to staphylococcal protein A. J. Immunol. 114: 1143-1146.

27. Moretta, L., M. Ferrarini, M. L. Durante, and M. C. Mingari. 1975. Expression of a receptor for IgM by human T cells in vitro. Eur. J. Immunol. 5: 565-569.

28. Moretta, L., M. Ferrarini, M. D. Mingari, A. Moretta, and S. R. Webb. 1976. Subpopulations of human T cells identified by receptors for immunoglobulins and mitogen responsiveness. J. Immunol. 117: 2171-2174.

29. Lobo, P. L., and D. A. Horwitz. 1976. An appraisal of Fc receptors on human blood B and L lymphocytes. $J$. Immunol. 117: 939-943.

30. Horwitz, D. A., and M. A. Garrett. 1977. Distinctive functional properties of human blood L lymphocytes: a comparison with T lymphocytes, B lymphocytes, and monocytes. J. Immunol. 118: 1712-1721.

31. Yoshida, T. O., and B. Anderson. 1972. Evidence for a receptor recognizing antigen complexed immunoglobulin on the surface of activated mouse lymphocytes. Scand. J. Immunol. 1: 401-408.

32. Anderson, C. L., and H. M. Grey. 1974. Receptors for aggregated IgG on mouse lymphocytes. Their presence on thymocytes, thymus-derived, and bone marrow-derived lymphocytes. J. Exp. Med. 139: 1175-1188.

33. Winchester, R. J., S. M. Fu. T. Hoffman, and H. G. Kunkel. 1975. IgG on lymphocyte surfaces: technical problems and the significance of a third cell population.J. Immunol. 114: $1210-1212$.

34. Gale, R. P., J. Zighelboim, R. C. Ossorio, and J. L. Fahey. 1975. A comparison of human lymphoid cells in antibodydependent cellular cytotoxicity (ADCC). Clin. Immunol. Immunopathol. 3: 377-384.

35. Calder, E. A., S. J. Urbaniak, W. J. Penhale, and W. J. Irvine. 1974. Characterization of human lymphoid cellmediated antibody-dependent cytotoxicity (LDAC). Clin. Exp. Immunol. 18: 579-593.

36. West, W. H., C. W. Sienknecht, A. S. Townes, and R. B. Herberman. 1976. Performance of a rosette assay between lymphocytes and sheep erythrocytes at elevated temperatures to study patients with cancer and other diseases. Clin. Immunol. Immunopathol. 5: 60-66.

37. West, W. H. 1977. Immunodiagnosis of Cancer. R. B. Herberman and K. R. McIntire, editors. Marcel Dekker, Inc., New York. In press.

38. Nelson, D. L., B. M. Bundy, H. E. Pitchon, R. M. Blaese, and W. Strober. 1976. The effector cells in human peripheral blood mediating mitogen-induced cellular cytotoxicity and antibody-dependent cellular cytotoxicity. J. Immunol. 117: 1472-1481.

39. Nelson, D. L., W. Strober L. D. Abelson, B. M. Bundy, and D. L. Mann. 1977. Distribution of alloantigens on human $F_{c}$ receptor-bearing lymphocytes: the presence of $B$ cell alloantigens on sIg-positive but not sIg-negative lymphocytes. J. Immunol. 118: 943-946.

40. Kroop, I. G., and H. H. Shackman. 1954. Level of serum C-reactive protein, as a measure of acute myocardial infarction. Proc. Soc. Exp. Biol. Med. 86: 95-97.

41. Shetler, M. R., J. A. Bullock, C. L. Shetler, and R. W. Payne. 1955. Comparison of serum C-reactive protein, glycoprotein, and seromucoid in cancer, arthritis, tuberculosis, and pregnancy. Proc. Soc. Exp. Biol. Med. 88: 107-109.

42. Hurlimann, J., G. J. Thorbeoke, and G. M. Hochwald. 1966. The liver as the site of C-reactive protein formation. J. Exp. Med. 123: 365-378.
43. Kushner, I., and M. H. Kaplan. 1961. Studies of acute phase protein. I. An immunohistochemical method for the acute localization of Cx-reactive protein in rabbits. Association with necrosis in local inflammatory lesions. J. Exp. Med. 114: 961-974.

44. Gottlieb, A. A. 1962. Kinetics of formation of Cx-reactive protein. Proc. Soc. Exp. Biol. Med. 110: 568-571.

45. Kushner, I., L. Rakita, and M. H. Kaplan. 1963. Studies of acute phase protein. II. Localization of Cx-reactive protein in heart induced myocardial infarction in rabbits. J. Clin. Invest. 42: 286-292.

46. Kushner, I., W. N. Ribich, and J. B. Blair. 1975. Regulation of C-reactive protein (CRP) synthesis: studies in isolated perfused rabbit liver. Fed. Proc. 34: 620. (Abstr.)

47. Crockson, R. A., C. J. Payne, A. P. Ratcliff, and J. F. Soothill. 1966. Time sequence of acute phase reactive proteins following surgical trauma. Clin. Chim. Acta. 14: 435-441.

48. McConkey, B., R. A. Crockson, and A. P. Crockson. 1972. The assessment of rheumatoid arthritis. A study based on measurements of the serum acute-phase reactants. Q. J. Med. 41: 115-125.

49. Moretta, L., S. R. Webb, C. E. Grossi, P. M. Lydyard, and M. D. Cooper. 1976. Functional analysis of two subpopulations of human T-cells and their distribution in immunodeficient patients. Clin. Res. 24: 448A. (Abstr.)

50. Moretta, L., S. R. Webb, C. E. Grossi, P. M. Lydyard, and M. D. Cooper. 1977. Functional analysis of two human T-cell subpopulations: help and suppression of Bcell responses by $\mathrm{T}$ cells bearing receptors for $\mathrm{IgM}$ or IgG. J. Exp. Med. 146: 184-200.

51. Siegel, J., R. Rent, and H. Gewurz. 1974. Interactions of C-reactive protein with the complement system. I. Protamine-induced consumption of complement in acute phase sera. J. Exp. Med. 140: 631-647.

52. Siegel, J., A. P. Osmand, M. Wilson, and H. Gewurz. 1975. Interactions of C-reactive protein with the complement system. II. CRP-mediated consumption of complement by poly-L-lysine polymers and other polycations. J. Exp. Med. 142: 709-721.

53. Mortensen, R. F., and H. Gewurz. 1976. Effects of Creactive protein on the lymphoid system. II. Inhibition of mixed lymphocyte reactivity and generation of cytotoxic lymphocytes. J. Immunol. 116: 1244-1250.

54. Fiedel, B. A., and H. Gewurz. 1976. Effects of C-reactive protein on platelet function. I. Inhibition of platelet aggregation and release reaction. J. Immunol. 116: 12891294.

55. Mortensen, R. F., A. P. Osmand, T. F. Lint, and H. Gewurz. 1976. Interaction of C-reactive protein with lymphocytes and monocytes: Complement-dependent adherence and phagocytosis. J. Immunol. 117: 774-781.

56. Volanakis, J. E., and M. H. Kaplan. 1971. Specificity of $\mathrm{C}$-reactive protein for choline phosphate residues of pneumococcal C-polysaccharide. Proc. Soc. Exp. Biol. Med. 136: 612-614.

57. Volanakis, J. E., and M. H. Kaplan. 1974. Interaction of C-reactive protein with the complement system. II. Consumption of guinea pig complement by CRP complexes; requirement for human Clq. J. Immunol. 113: 9-17.

58. Leuker, R. D., and R. C. Williams, Jr. 1972. Decreased reactivity of lymphocytes in mixed leukocyte culture from patients with rheumatic fever. Circulation. 46: 655-660.

59. Read, S. E., V. A. Fischetti, V. Utermohlen, R. E. Falk, and J. B. Zabriskie. 1974. Cellular reactivity studies to streptococcal antigens. Migration inhibition studies in patients with streptococcal infections and rheumatic fever. J. Clin. Invest. 54: 439-450. 